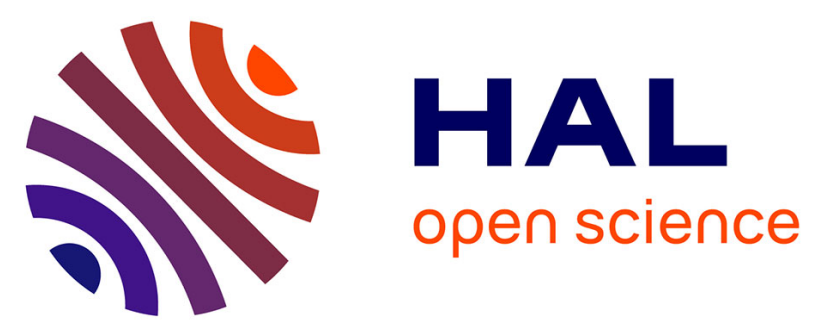

\title{
Effects of the Erika oil spill on the common starfish Asterias rubens, evaluated by field and laboratory studies.
}

Guillemette Joly-Turquin, Philippe Dubois, Geoffroy Coteur, Bruno Danis, Sandra Leyzour, K. Le Ménach, Hélène Budzinski, Monique Guillou

\section{To cite this version:}

Guillemette Joly-Turquin, Philippe Dubois, Geoffroy Coteur, Bruno Danis, Sandra Leyzour, et al.. Effects of the Erika oil spill on the common starfish Asterias rubens, evaluated by field and laboratory studies.. Archives of Environmental Contamination and Toxicology, 2009, 56 (2), pp.209-220. 10.1007/s00244-008-9176-8 . hal-00460061

\section{HAL Id: hal-00460061 https://hal.univ-brest.fr/hal-00460061}

Submitted on 26 Feb 2010

HAL is a multi-disciplinary open access archive for the deposit and dissemination of scientific research documents, whether they are published or not. The documents may come from teaching and research institutions in France or abroad, or from public or private research centers.
L'archive ouverte pluridisciplinaire HAL, est destinée au dépôt et à la diffusion de documents scientifiques de niveau recherche, publiés ou non, émanant des établissements d'enseignement et de recherche français ou étrangers, des laboratoires publics ou privés. 
Effects of the Erika oil spill on the common starfish Asterias rubens, evaluated by field and laboratory studies.

Guillemette Joly-Turquin ${ }^{1,2}$, Philippe Dubois ${ }^{1}$, Geoffroy Coteur $^{1}$, Bruno Danis ${ }^{1}$, Sandra Leyzour $^{2}$, Karine Le Menach ${ }^{3}$, Hélène Budzinski $^{3}$, Monique Guillou $^{2 *}$

1. Laboratoire de Biologie Marine (CP 160/15), Université Libre de Bruxelles, 50 Av. F.D. Roosevelt, B-1050 Bruxelles, Belgium.

2. Laboratoire de l'Environnement Marin (UMR 6539), Université de Bretagne Occidentale, Institut Européen de la Mer, place N. Copernic, F-29780 Plouzané, France.

3. LPTC UMR CNRS 5472, Université de Bordeaux, 351, crs de la Libération, 33405 Talence, France.

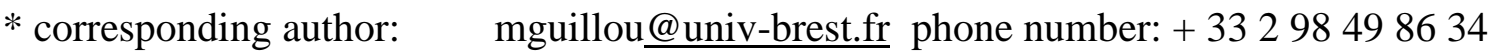
Fax: + 32298498645

\begin{abstract}
Impacts of the 'Erika' oil spill on the common starfish Asterias rubens were investigated in the field, and using laboratory experiments based on contamination via food at different stages of the starfish reproductive cycle. Two months after the shipwreck, levels of hydrocarbons characteristic of 'Erika' fuel were significantly higher in pyloric caeca and body wall of A. rubens from a contaminated site, compared with control animals from an unpolluted reference area. Concomitant immunological responses and detoxification enzyme activity (CYP1A) were enhanced in the impacted starfish, suggesting rapid biotransformation processes. This was confirmed by laboratory experiments which showed a fast PAH uptake during the 10 first days of contamination, and the start of biotransformation processes from the third day. Our study confirms benzo(a)pyrene hydroxylase activity (BPH) in A. rubens and demonstrates the influence of CYP1A in the conversion of insoluble PAHs into soluble derivatives in this species for the first time. The rapidity of decontamination could explain
\end{abstract}


why starfish growth, level of motile activity, reproductive investment, energy storage and larval development were not significantly affected by these contaminants.

Keywords: Asterias rubens; Erika oil spill; Polycyclic aromatic hydrocarbons; biomarkers; growth; reproduction.

\section{INTRODUCTION}

In December 1999, the oil tanker "Erika" sank off the coast of southern Brittany (France), breaking in two and releasing approximately 19000 metric tons of heavy fuel oil $\left(\mathrm{N}^{\circ} 2\right.$ or 6 according to the French or British classifications, respectively) along $400 \mathrm{~km}$ of the French Atlantic coast (Laubier et al., 2004, Fig. 1). The substance released was not a true crude oil, but a residue of petroleum transformation characterized by high molecular weight PAHs, a specific gravity similar to seawater and a high viscosity $\left(20,000 \mathrm{cSt}\right.$ at $\left.10^{\circ} \mathrm{C}\right)$. It was composed of about $50 \%$ PAHs with a high predominance of chrysene, phenanthrene, pyrene and benzo(a)anthracene (INERIS, National Institute for Environment and Industrial Risk, Diderich, 2000). The main oil discharges from the wrecked tanker occurred between 24 and 27 Dec and fouled the upper parts of the shorelines of Loire Atlantique and Vendée counties. In order to study the ecological and ecotoxicologic consequences of this oil spill, the French Ministry of Ecology and Sustainable Development launched a monitoring program, managed by IFREMER (French Research Institute for the Exploitation of the Sea) and INERIS. Two to three months after the oil spill, PAHs were found in every compartment of the environment, the main types detected being alkyl-substituted phenanthrenes, pyrenes, chrysenes and heterocyclic sulfur compounds as dibenzothiphenes and its alkyl derivatives (Tronczynski et al., 2004). Moreover, evidence of contamination associated with Erika oil was still detectable 
in water and suspended particulate matter in May 2002. However, the shallow subtidal sediments exhibited little sign of oil contamination at any time.

Mass mortalities of the starfish species Asterias rubens and Marthasterias glacialis were observed on the highly polluted shore of the Croisic headland (Loire Atlantique) a few days after the spill (Bruet, personal communication). A. rubens is a common marine predator of the Atlantic coast and has been frequently used as a bio-indicator of contamination of the benthic environment by heavy metals and polychlorinated biphenyls (Coteur et al., 2003b,c; Danis et al., 2004b; den Besten et al., 2001; Guns et al.,1999; Stronkhorst et al., 2003; Temara et al., 1998). The expression of $A$. rubens cytochrome P450 immunopositive protein (Danis et al., 2004a; den Besten et al., 1993) and immune response (Coteur et al., 2005) are among the biomarkers used for such toxicity studies. Moreover, contaminated sediments from the North Sea were proven to have deleterious effects on embryo development of this species (Coteur et al., 2003b). The finding of sublethal effects on A. rubens skeletogenesis and growth following contamination by heavy metals (Temara et al., 1997, 1998) suggests that pollution could also have an impact on the demographic parameters of the species.

The literature contains few reports about the effects of oil spillage on starfish populations, apart from some monitoring carried out after the Exxon Valdez oil spill (Dean et al., 1996; Hooten and Highsmith, 1996; Jewett et al., 1996). However, as these field studies dealt with density measurements, it is difficult to dissociate effects of the oil from those of other factors like post-spill shoreline treatments, the use of dispersants, or even natural cycles. Previous experimental studies have mostly been focused on the impact of the water accommodated fraction (WAF) or water soluble fraction (WSF) of crude oil on the survival, behavior or feeding of predatory starfish including Asterias rubens (Georgiades et al., 2003; O'Clair and Rice, 1985; Ordzie and Garofalo, 1981; Temara et al., 1999; reviewed by O'Clair and Rice, 1985). Locomotive function, prey localization ability, feeding rates and growth have all been 
found to be reduced at low oil concentrations, even though sensitivity was shown to vary with the type of oil and/or starfish species. Ability to avoid oiled sediment was also demonstrated in one bottom-dwelling starfish (Ryder et al., 2004).

The present study, therefore, aimed not only to quantify the effects of the Erika oil spill on biomarker expression in Asterias rubens, i.e. cytochrome P450 (CYP1A) and immune responses, but also to determine whether such pollution would have an impact on the growth or reproductive cycle. Effects on growth and reproduction were investigated through controlled laboratory experiments, using oil-polluted mussels as a food supply for starfish. These experiments also aimed to investigate PAH uptake and loss over time in the digestive structures of $A$. rubens, in order to determine possible relationships between the presence of PAHs in starfish and the biological effects observed.

\section{MATERIALS AND METHODS}

\section{Field survey}

The field survey of the effects of the Erika oil spill on Asterias rubens populations was conducted by sampling starfish from two intertidal populations: Piriac (Croisic headland), contaminated by the Erika oil spill on December 251999 (Laubier et al., 2004), and Aber (Bay of Douarnenez, Fig. 1) which remained free of pollution.

Both field sites were visited at low tide to collect starfish on days 40 (Feb 00), 58 (Feb 00), 221 (Aug 00), and 2 years after the oil spill (Jan 02). Individuals with a 50 to 70 -mm-long ray were sampled (the ray corresponds to the size of the longest arm measured from mouth to tip with a Vernier caliper). On day 40 no starfish were found at Aber, and the 5 starfish collected at Piriac the same day were used for immune response measurements. On days 58, 221 and 2 years after the oil spill, 4 starfish from each site were dissected in the field for cytochrome P450 immunopositive protein induction measurement (CYP1A): $2 \mathrm{ml}$ of pyloric caeca were 
blotted, immediately frozen in liquid nitrogen and stored at $-80^{\circ} \mathrm{C}$ until analysis. On days 58 and 221, another ten starfish were brought to the laboratory where they were kept for 24 hours in aquaria supplied with clean running sea water prior to immune response measurements. On day 58 and 2 years after the oil spill, 10 starfish from each site were dissected for PAH analysis; 2 pools of pyloric caeca and 2 pools of body wall were made (10 starfish per pool) and stored at $-20^{\circ} \mathrm{C}$.

Cytochrome P450 immunopositive protein induction measurement (CYP)

The P450 immunopositive protein (CYP1A-IPP) contained in the post-mitochondrial fraction of the pyloric caeca was quantified using a competitive ELISA method as described by Danis et al. (2004a). The final results were expressed as inhibition factors, i.e. the ratio of CYP1AIPP levels between experimental and control groups.

\section{Immune response measurement}

The two essential parameters of the starfish immune system considered in this study were coelomic amoebocyte concentration (CAC) and reactive oxygen species (ROS) production by resting (unstimulated) or stimulated amoebocytes. Amoebocyte ROS production was measured by the peroxidase luminol-enhanced chemiluminescence (PLCL), method developed by Coteur et al. (2002, 2004, 2005). Measurements were normalized using the actual amoebocyte concentration in each sample, and expressed as the sum of all 10-min interval measurements (in Relative Light Units RLU, an internal scale of the instrument) for $10^{6}$ cells $\mathrm{ml}^{-1}$ (total chemiluminescence) of resting or stimulated amoebocytes.

\section{PAH measurements}

For quantification of the PAHs listed in Table 1, tissue samples were freeze-dried and ground prior to analysis. Among the alkylated PAHs, only certain compounds of high molecular weight, known to be representative of the crude oil from the Erika, and highly abundant, were chosen for measurement. PAHs were extracted from 1 to $3 \mathrm{~g}$ of dry tissues using the 
microwave-assisted extraction method described by Budzinski et al. (1999). Filtration of the extracts, reduction of their volume and purification were performed as described by Baumard and Budzinski (1997). Experimental blanks were also passed to assess the risk of potential contamination. Extracts were analyzed by HP GC/MSD according to the procedure used by Geffard et al. (2004) in the Erika monitoring program, except for the oven temperature which was programmed to increase by $2^{\circ} \mathrm{C} / \mathrm{min}$ from $70{ }^{\circ} \mathrm{C}$ to $300{ }^{\circ} \mathrm{C}$ in the present study. Different perdeuterated PAHs were used as internal standards for each class of aromaticity (Baumard and Budzinski, 1997). The response factor of a given PAH relative to the perdeuterated one was determined for each GC/MS sequence by injecting $1 \mu \mathrm{L}$ of a standard solution containing a mixture of PAHs (SRM 2260, National Institute of Science and Technology, Gaithersburg, MD, USA) and the solution of perdeuterated PAHs used for sample spiking. The precision of this type of quantification has been evaluated to be between $88 \%$ and $98 \%$, depending on the compound, with reproducibility between $2 \%$ to $5 \%$. The entire analytical procedure was performed several times with certified mussel tissue, SRM 2974 (NIST, Gaithersburg, MD, USA). The recoveries on this SRM were between $70 \%$ and $110 \%$ for five replicates with reproducibility ranging from 7 to $17 \%$ depending on the compound.

\section{Laboratory studies}

Our laboratory investigations complemented the field study by aiming to assess to what extent starfish somatic growth, reproduction, and development of gametes and larvae were affected by oil exposure via food. Experiments were performed on starfish at different stages of development and reproductive cycle. Uptake and loss of PAHs over time were also analyzed.

\section{Experimental procedure}

Mussels were exposed for 3 days to 'Erika oil' samples, supplied by the CEDRE (Centre of documentation, research and experimentation on accidental water pollution, Brest, France),. A preliminary study had first been carried out to establish a protocol to produce a PAH 
concentration in mussels that would be close to the maximum PAH content observed in the mussels in the Bay of Vilaine after the oil spill (sum PAH $=2536 \mu \mathrm{g} \mathrm{kg}^{-1} \mathrm{dw}$ in February 2000, Tronczynski et al., 2004). A PAH concentration of $3420 \mu \mathrm{g} \mathrm{kg}^{-1}$ (268.5 $\mu \mathrm{g} \mathrm{g}^{-1}$ lipids $) \pm$ $900 \mu \mathrm{g} \mathrm{kg}^{-1}$ (mean PAH concentration in 3 replicates of $30 \mathrm{~g} \mathrm{WW}$ of mussel soft tissue) was obtained after 3 days of contamination with the following method: $1500 \mathrm{~g}$ of mussels were placed in an aquarium containing 21 seawater and 50 g Erika oil (25 g. $1^{-1}$ oil $)$. The aquarium was covered and the soluble phase homogenized by high air bubbling. After contamination, the mussels were carefully brushed and cleaned to eliminate any traces of oil. The PAH concentration in the control mussels was $14 \mu \mathrm{g} \mathrm{g}^{-1}$ lipids. Contaminated and uncontaminated mussels of the same origin were frozen following treatment and prior to use as food. One should note that after 24 hours in running seawater, the frozen mussels showed no significant decrease in PAH content $\left(222 \pm 134.3 \mu \mathrm{g} \mathrm{g}^{-1}\right)$. Starfish were fed at the rate of 1 mussel per individual per day.

Two treatments were used in the laboratory experiments: 'contaminated treatment' and 'control treatment' depending on whether the mussels supplied as food to starfish were contaminated or not (details of the separate experiments are given below under Experiment descriptions). For each experiment, the aquaria were filled with clean running seawater from the nearby Bay of Brest; salinity ranged from 33 to 35 PSU. Once a week, the photoperiod was adjusted to match the natural one. The mussels fed to each starfish were chosen according to the size of the starfish under test, according to the relation established by Sommer et al. (1999) (mussels of 2 to 50-mm shell length for starfish of 5 to $65 \mathrm{~mm}$ ray length).

\section{Parameters measured}

The parameters studied were: size structure, gonad and pyloric caeca indices, PAH concentrations, righting activity coefficient (RAC), ovocyte diameter, fertilization success, 
embryo development and adambulacral spine regeneration. The parameters assessed depended on the particular experiments.

Before the experiments were started, starfish size distribution was carefully checked for likeness between the groups used for the different treatments. Pyloric and gonad indices were calculated as follows: organ index = organ dry weight / body wall dry weight. Gonads and pyloric caeca were dissected, and the body wall was carefully cleaned. Body compartments were dried separately at $60^{\circ} \mathrm{C}$ for 48 hours and weighed.

RAC is indicative of the level of motion activity (Watts and Lawrence, 1990). Here, the righting time corresponded to the time required by a starfish to turn back over once it had been placed on its aboral face. RACs were calculated as follows: $\mathrm{RAC}=1000$ / righting time (s). Among individuals, those showing no sign of righting response initiation within 10 minutes were assigned an RAC value of $1000 /(2 * 600)$.

Histological observations were made to detect any effect that oil pollution had on ovocyte diameter. Ovary samples were embedded in paraffin, sectioned into 5 - $\mu$ m-thick slices and colored using Trichrome staining. For each female, digital pictures of 100 ovocytes exhibiting a nucleolus and a nucleus within a same section were taken with a CCD camera (Iris Sony) and measured with Visilog 4.0 software; diameters were then obtained by conversion.

Fertilization assays were made to assess the capacity of starfish ovocytes to be fertilized, as well as the quality of subsequent larval development. Starfish were sexed by puncture of gonadic material through the integument. Spawning and fertilization were performed as described by Coteur et al. (2003b). Individual female clutches were fertilized by a pool of sperm ( 3 males). Fertilization success was assessed after 1 h by counting the number of eggs with a fertilization membrane in 3 subsamples of 100 eggs each and the embryo development quality was determined after $72 \mathrm{~h}$. For each fertilization, the different types of larvae (viable larvae, abnormal larvae and dead eggs) were counted in each well of a six-well plate . 
Adambulacral spine regeneration was induced and studied according to the methods developed by Dubois and Jangoux (1990).

\section{Experiment descriptions}

\section{Impact of PAH uptake on adults at the gametogenic stage: a 3-month experiment}

Two laboratory experiments (named $1 \mathrm{~A}$ and $2 \mathrm{~A}$, respectively) were carried out over three months in two successive years. These were conducted during the period of gonadal growth from December to the end of February. In each treatment (contaminated and control), 60 starfish of 35-45 $\mathrm{mm}$ ray length were used (10 per aquarium).

\section{$\underline{\text { Monitoring PAH uptake and its potential physiological effects: a short15-day experiment }}$}

This experiment (named PAH uptake) was conducted in June during the agametogenic stage on starfish of 50-70 mm ray length. PAH accumulation in pyloric caeca (pool of 10 starfish per aquarium) and the RAC values were measured on days $0,1,2,5,7,10$ and 15 of exposure to oil. The regenerating adambulacral spines were sampled on five starfish in each treatment, 15 days after fracture, and the regeneration size (RAS) measured with a scanning electron microscope as previously described by Dubois and Jangoux (1990).

For the sum of all measured PAHs, the sum of parental PAHs and PAHs of particular interest in this study, PAH uptake vs. time was tentatively modeled with the following quadratic equation:

$C_{P A H}=a T^{2}+b T+c$,

where $C_{P A H}$ is the concentration of the PAH concerned, $T$ is the time-length expressed in days of exposure to contamination, and $a, b, c$ are constants. The inflection point of the curve, $I$, corresponded to $I=-b / 2 a$. The transfer factor (TF) of a given $\mathrm{PAH}$ in this study corresponded to the ratio of its concentration in the pyloric caeca (i.e. the mean of data at days 10 and 15$)$ to that in the food ( $\mu \mathrm{g} \mathrm{g}^{-1}$ lipids).

\section{Decrease of PAHs in the pyloric caeca: a 24-day experiment}


Juvenile starfish of about $20 \mathrm{~mm}$ ray length were contaminated over 4 months (from May to September) in the conditions previously described. In September they had grown to 40-65 $\mathrm{mm}$ ray length. Contaminated and control starfish were then both fed with pollution-free mussels for 23 days. Temperature was constant and verified daily during the experiment (17.5 $\pm 0.15{ }^{\circ} \mathrm{C}$ ). Pyloric index (fresh weight) and RAC value were determined on 4 starfish per treatment on days $0,1,2,4,7,10,14,18$ and 23 of the PAH loss experiment. For the sum of all measured PAHs, the sum of parental PAHs and PAHs of particular interest in this study, PAH loss by starfish was tentatively modeled using the following equation:

$C_{P A H}=d \times e^{-k T}+g$

where $C_{P A H}$ is the concentration of the concerned PAHs, $T$ is the number of days under PAH loss conditions, and $d, k$ and $g$ are constants. The biological half lives of the different compounds were estimated as $\mathrm{Tb}=\ln 2 / \mathrm{k}$.

\section{Statistical analysis}

The measured immune responses (ROS production and CAC) were compared between treatments using nonparametric tests since the data that did not fit a normal distribution and CYP1A expression were tested with two-way ANOVA. In the laboratory contamination trials, gonad and pyloric indexes, PAH levels and physiological parameters were inter-compared and statistically tested using t-tests or ANOVAs, depending on the number of samples. In experiments requiring the use of several aquaria for each treatment, differences in the variables (measured on all individuals) were tested using a nested ANOVA with "aquarium" as a nested factor within "treatment". The nested factor allows one to distinguish any discrepancy between pseudo-replicates within each experimental treatment (Zar, 1996).

PAH uptake and loss were modeled by quadratic curve fitting with Systat 9 software. Residuals were plotted, and checked to ensure there was no serial correlation. 
Whenever several statistical comparisons were performed either on the same set of data or on subsets, we used the Bonferroni criterion and divided by the number of comparisons.

\section{RESULTS}

\section{Field survey}

Fifty-eight days after the oil spill, the PAH levels in the pyloric caeca and body wall of starfish from Piriac were higher than those in starfish from Aber (Fig. 2). The amounts were particularly high in pyloric caeca compared with the body wall. The most abundant PAHs in the fuel transported by the Erika were analyzed in starfish samples; these were alkyl substituted homologues of phenanthrene (Phe), dibenzothiophene (DBT) and chrysene (Chrys) (Tronczynski et al., 2004), and their unsubstituted PAHs. Chrysene and its alkylated homologues were far more abundant in starfish from Piriac than in controls for both organs studied (Table 2). Moreover, the pyloric caeca of Piriac starfish contained more Phe-alkylated homologues and less DBT and DBT-alkylated homologues than did the body walls.

Figure 3 illustrates the changes occurring over time in the responses of the biomarkers according to sampling site. At day 58, ROS production by both resting and stimulated amoebocytes (Mann-Whitney $p \leq 0.005, \mathrm{n}=19$ ), CAC and CYP1A levels were significantly higher in starfish from Piriac than in those from Aber. However, at day 221, only CAC (Mann-Whitney $p \leq 0.005, \mathrm{n}=37$ ) and CYP1A levels were more elevated (two-way ANOVA, factor: site $p=110^{-8}, \mathrm{n}=16$ ).

The immune response parameters showed contrasting results (Fig. 3): at Piriac, ROS production by both resting and stimulated amoebocytes was significantly higher at day 40 than at day 58 (Kruskall-Wallis $p=0.007, \mathrm{n}=23$ ), CAC response however showed no significant difference between the two dates. ROS production by both resting and stimulated amoebocytes and CAC levels did not significantly change between days 58 and 221 at Piriac. 
At Aber in contrast, amoebocyte ROS production (of both types) was higher on day 221 than on day 58 (Mann-Whitney $p \leq 0.01, \mathrm{n}=19$ ). CYP1A levels were higher on day 58 than on day 221 in both populations (two-way ANOVA, factor: time, $p=2310^{-8}, \mathrm{n}=16$ ).

In January 2002 (after 2 years), starfish from both sites had a low PAH content with respect to lipids (Fig. 2); moreover, no significant difference was found between mean CYP1A expression at Aber $(2.12 \pm 0.87)$ and Piriac $(1.90 \pm 0.71)(t$-test $p=0.70)$.

\section{Laboratory studies}

Impact of PAH uptake on adults at the gametogenic stage: a 3-month experiment

The three-month experimental contamination (experiment 1A) showed an accumulation of PAHs in the pyloric caeca of contaminated starfish $\left(49.3 \pm 18.8 \mu \mathrm{g} \mathrm{g}^{-1}\right.$ lipids $v s .1 .7 \pm 0.7 \mu \mathrm{g}$

$\mathrm{g}^{1}$ lipids in the control) and in their gonads $\left(32.2 \pm 6.7 \mu \mathrm{g} \mathrm{g}^{-1}\right.$ lipids $v s .0 .4 \pm 0.2 \mu \mathrm{g} \mathrm{g}^{-1}$ lipids in the control). Differences were highly significant between treatments (two-way ANOVA, $\left.p=110^{-4}\right)$ but not significantly different between body compartments $(p=0.170)$ or treatment $\mathrm{x}$ body compartment interaction $(p=0.199)$. PAH uptake was the same in pyloric caeca and gonads. Apart from RAC values, which were higher in experiment $1 \mathrm{~A}$ in contaminated starfish than in controls ( $t$-test, $p=0.02, \mathrm{n}=36$ ), no other significant differences were shown between control and contaminated treatments in the parameter measured: i) mean size ( $t$-test, $p=0.81,0.13$ with $\mathrm{n}=63,50$ for experiments $1 \mathrm{~A}$ and $2 \mathrm{~A}$ respectively), ii) gonad index ( $t$ test, $p=0.43$ with $\mathrm{n}=63$ in experiment $1 \mathrm{~A})$, iii) pyloric index ( $t$-test, $p=0.26,0.26$ with $\mathrm{n}=63,50$ for experiments $1 \mathrm{~A}$ and $2 \mathrm{~A}$ respectively) and iv) ovocyte diameters (t-test, $p=0.81$ with $n=10$ in experiment $1 \mathrm{~A})$.

Spawning and fertilization were induced at the end of these experiments. At least $90 \%$ of eggs presented a fertilization membrane demonstrating their fertilization quality. No significant difference was found in the percentage of dead eggs and viable larvae between larval batches 
produced from contaminated or uncontaminated parents (ANOVA, $p=0.76$; $t$-test, $p=0.95$, $\mathrm{n}=12)$

\section{Monitoring PAH uptake and its potential physiological effects: a short15-day experiment}

Starfish in the contamination treatment consumed the same number of mussels as control starfish. During this experiment the changes in daily sea water temperature were low (15.4 \pm $0.4^{\circ} \mathrm{C}$ ). The patterns of PAH accumulation in the pyloric caeca appeared to be the same for unsubstituted and alkylated PAHs (Fig. 4; Table 3): the marked uptake observed in the first days in the two pools analyzed from contaminated starfish was followed by a decrease between days 9 and 10. Transfer factors were always less than 0.2 . The evolution over time in the ratios of benzo(e)pyrene $(\mathrm{BeP})$ to benzo(a)pyrene $(\mathrm{BaP})$, and the ratios of some parent PAHs: chrysene, phenanthrene and dibenzothiophene to their more hydrophobic methylsubstituted compounds showed a preferential accumulation of the more soluble PAHs over the first 3 days of the experiment, except for the chrysene family (Fig. 5). Such an evolution is indicative of a biotransformation process. A slight rise in chrysene was noted throughout the experiment. An accumulation of DBT and Phe during the first days was followed by a large increase in methyl-substituted compounds from the $5^{\text {th }}$ day. From the $2^{\text {nd }}$ day BeP increased faster than $\mathrm{BaP}$ indicating preferential metabolisation of $\mathrm{BaP}$ compared with $\mathrm{BeP}$. After the $7^{\text {th }}$ day, none of these ratios changed very much. Overall contamination of starfish under controlled conditions showed no evolution over time though, with the sum of analyzed PAHs remaining within the range 0.3 to $0.6 \mu \mathrm{g} \mathrm{g}^{-1}$ lipids.

No differences were observed in RAC, pyloric indexes or size of regenerating adambulacral spines between the two groups of contaminated starfish ( $t$-tests, $p>0.05)$, and mean RAC showed no temporal evolution whatever the treatment (Pearson correlation coefficients $r=-$ $0.492,-0.573$ and -0.502 respectively for control starfish, contaminated starfish in aquaria 1 and 2, $p \geq 0.2, \mathrm{n}=7$ for each). As the starfish consumed food during the experiment and 
accumulated reserves throughout the agametogenic stage, their pyloric indices under both contaminated and control conditions were higher compared to those measured at the beginning of the experiment (Day 0) (ANOVA, $p=4.10^{-4}, \mathrm{n}=40$ ), but no difference was detected between treatments ( $t$-test, $p>0.1)$. Similarly, neither RAC values, nor the sizes of regenerating adambulacral spines were found to differ between contaminated and control starfish ( $t$-test, $p=0.68$ and $0.344, \mathrm{n}=30$ and 14 respectively).

Decrease of PAHs in the pyloric caeca: a 24-day experiment

Mean daily sea water temperature in the tanks $\left(17.5 \pm 0.1^{\circ} \mathrm{C}\right)$ did not change during this experiment. PAH levels decreased rapidly in the pyloric caeca (Fig. 6), and calculated halflives were within 2 and 4 days (Table 4). After 23 days of PAH loss, most of the individual PAHs of particular interest were close to zero apart from a few PAHs including Pyrene, Chrysene and phenanthrene that had concentrations much higher than in the control. No significant differences in RAC were observed between treatments or days (two-way ANOVA $p=0.23,0.39$ and 0.75 for the factors "treatment", "days" and their interaction, respectively, $\mathrm{n}=74$ ). No significant difference was detected in pyloric indices between decontaminated starfish $(\mathrm{PI}=0.496 \pm 0.099)$ and the control $(\mathrm{PI}=0.440 \pm 0.064 ; t$-test, $p=0.12, \mathrm{n}=74)$.

\section{DISCUSSION}

\section{Biomarker expression and PAH dynamics in Asterias rubens pyloric caeca}

This study has provided evidence for contamination of the pyloric caeca and body wall of Asterias rubens in the field by the oil from the Erika, spilt along the shoreline of South Brittany over the first weeks following the shipwreck. Less than two months after the event, high PAH levels characteristic of fuel from the Erika were detected in pyloric caeca of starfish at Piriac. Reactive oxygen species (ROS) production by resting or stimulated amoebocytes and coelomic amoebocyte concentration (CAC) were simultaneously enhanced in the 
impacted starfish. A high induction of CYP1A expression was also observed. CYP1A converts particularly insoluble organic compounds such as PAHs and PCBs (Bucheli and Fent, 1995) into soluble derivatives. The induction of CYP1A expression by exposure to PCBs had already been reported in the pyloric caeca of $A$. rubens (Danis et al., 2004a,b) but the present study is the first time that a high reactive signal was clearly observed in presence of PAHs. These biomarker expression patterns suggest a rapid initiation of the biotransformation process.

Laboratory experiments confirm this hypothesis and allow a better understanding of the dynamics of some specific aromatic hydrocarbons. While PAH uptake within the pyloric caeca of adult starfish fed with oil-polluted mussels was fast (the peak concentration was reached in 8 to 10 days after the start of contamination), elimination and biotransformation were also rapid; even in conditions with a constant supply of contaminated food. The most soluble compounds, apart from the chrysene family, were preferentially accumulated over the first few days. Indeed, among the PAH parent compounds under study, chrysene was the only one that showed a continuous increase in relation to its alkylated homologues during the 15 days of the PAH uptake experiment. This indicated that it was not biotransformed, in contrast to benzo(a)pyrene, whose biotransformation was induced in the first days of contamination. Benzo(a)pyrene is more reactive and oxidizable than benzo(e)pyrene (Baumard et al. 1999) and the observation of benzo(a)pyrene biotransformation is in agreement with the study of den Besten et al. (1993) where benzo(a)pyrene hydroxylase activity (BPH) was enhanced in the $A$. rubens pyloric caeca microsomes in the days immediately following injection of benzo(a)pyrene into the animals. Moreover, the low transfer factors of PAHs $(<1)$ in the pyloric caeca indicate that there was no biomagnification through the mussel-starfish trophic link. 
Following the end of the experimental pollutant exposure, half of the total PAHs were eliminated in the next 2 to 4 days. However, 20 days later, a certain amount of PAHs remained stored in the pyloric caeca. Experimental observations therefore suggest that despite clear evidence for rapid biotransformation processes, the longer the exposure to pollution continues, the greater the level of PAHs accumulated in the pyloric caeca. Table 5 shows that a constant supply of oil-polluted food lowered the biotransformation capability of starfish. Measured PAH concentrations were much lower in the field than under experimental conditions (24 times lower in the field 2 months after the oil spill than in the laboratory after 15 days of controlled contamination). It is also worth noting that the high oil concentrations found in mussels following the oil spill did not remain as constant as the contamination in controlled laboratory conditions.

Several biomarkers were used in this study to monitor the physiological response of starfish to PAHs in the field. All showed a significant enhancement in the impacted starfish compared with controls a few weeks after the oil spill. But although the CYP1A signal is clear, ROS production by starfish from the contaminated field site were within the range of the values found by Coteur et al. (2004) in natural uncontaminated populations, and CAC values were below those previously measured in heavily polluted locations (Coteur et al., 2003a,b). The kinetics of PAH loss previously described suggest that rapid decontamination could possibly be occurring and thus that there may be a reduction in ROS production during the $24 \mathrm{~h}$ that elapsed between starfish collection and response measurement. Such an explanation cannot account for the CAC result though, since immune cell turnover in marine invertebrates exceeds 24 hours (McIntosh and Robinson, 1999). CAC is known to be quite a robust biomarker for stress (Coteur et al., 2004), and the differences observed between the two populations would indeed have resulted from the PAH level in the field. However, as it is well known that environmental factors such as temperature can influence immune response in 
starfish (Coteur et al., 2004), the immune biomarker levels could have been modulated by changes in water temperature, notably in the impacted field site between days 40 and 58 .

\section{Effect of PAHs on Asterias rubens growth, reproduction and embryo development}

As observed in the present study, irrespective of which experiment is considered, neither growth nor reproductive capability of starfish was affected by $\mathrm{PAH}$ exposure, despite an increase of PAH content in the pyloric caeca. PAH accumulation in the gonads had no effect on ovocyte morphometry, and fertilization rates were only very slightly affected. To our knowledge, no previous study has dealt with the impact of oil contamination through food. Oil has previously been shown to induce damage to starfish locomotive function (O'Clair and Rice, 1985 and references therein, Ordzie and Garofalo, 1981), feeding rate and adult growth (Crapp, 1971; Georgiades et al., 2003; O'Clair and Rice, 1985; Temara et al., 1999), and embryo development (Davis et al., 1981). However, in these studies, the starfish were exposed either to the water accommodated fraction (WAF) of different types of oil or to a complex mixture of hydrocarbons and dispersants. Volatile and soluble oil fractions may have greater direct effects on echinoderms than compounds obtained via food. In the sea urchin, Paracentrotus lividus, the righting response was enhanced by the most volatile compounds of crude oil, but not by weathered crude oil (Axiak and Saliba, 1981). The effects of WAF are more harmful on embryo development in sea urchins (references in Kobayashi, 1995): adult exposure to polluted effluents can lead to egg abnormalities at the first cleavage stage (Vashchenko, 1980) or affect egg fertilization and sperm motility (Krause, 1994). It is not easy to determine whether the reported differences resulted from exposure conditions, pollutant sensitivity of the organism under study or levels of contamination, because none of these authors qualified or quantified the level of parental contamination. Once again, without additional data about the relative toxicity of PAHs, it does not seem relevant to speculate on 
whether volatile and soluble oil fractions are more or less toxic or bioaccumulated than PAHs taken in with food. Only Barron and et al. (1999) have suggested that PAHs are not necessarily the major determinant of WAF toxicity.

In conclusion, this study has demonstrated that uptake of PAHs via food is an important route for contamination of the common starfish A. rubens. Short-term impacts of oil contamination were easily quantified using detoxification biomarkers, immunological responses and by monitoring PAH uptake and loss in the storage organs. Moreover, A. rubens and suitable biomarkers (e.g. CAC or CYP1A) can be judged to be suitable for use as early warning signals for exposure to PAHs. However, behavior, reproduction and growth did not appear to be affected by PAH exposure through food. Finally, the present data showed no significant long-term effects of the Erika oil spill on A. rubens dynamics. The predation power of $A$. rubens thus appears to be unaffected in the mussel beds of the intertidal rocky temperate communities structured by this starfish.

Acknowledgments:

This study was supported by the French Ministry of Ecology and Sustainable Development within the framework of "Erika Monitoring" program, a CGRI-FNRS-CNRS co-operation agreement, and by French Research Ministry grant for $\mathrm{PhD}$ co-supervision. We are grateful to Ph. Pernet (ULB) and M. Le Meur (LPTC) for their help in the analytic and experimental work, to M. Briand for her help in the preparation of figures, and to Dr H. McCombie for revising the English. 


\section{REFERENCES}

Axiak V, Saliba, LJ (1981) Effect of surface and sunken crude oil on the behaviour of a sea urchin. Mar Pollut Bull 12:14-19.

Barron MG, Podrasbsky T, Ogle S, Ricker RW (1999) Are aromatic hydrocarbons the primary determinant of petroleum toxicity to aquatic organisms? Aquat Toxicol 46:253-268

Baumard P, Budzinski H, (1997) Internal standard quantification method and Gas

Chromatograph-Mass Spectrometer (GC-MS): a reliable tool for Polycyclic Aromatic Hydrocarbon (PAH) quantification in natural matrices. Analysis 25:246-252

Baumard P, Budzinski H, Garrigues P, Dizier H, Hansen PD (1999) Polycyclic Aromatic Hydrocarbons in recent sediments and mussels (Mytilus edulis) from the Western Baltic Sea : occurrence, bioavailability and seasonal variations. Mar Environ Res 47:17-47

Bucheli TD, Fent K (1995) Induction of cytochrome P450 as a biomarker for environmental contamination in aquatic ecosystems. Crit Rev Env Sci Tec 25:201-268

Budzinski H, Letellier M, Garrigues P, Le Menach K (1999) Optimisation of the microwave assisted extraction in open cell of PAHs from soils and sediments - Study of moisture effect. J Chromatogr A 837:187-200

Coteur G, Warnau M, Jangoux M, Dubois Ph (2002) Reactive oxygen species (ROS) production by amoebocytes of Asterias rubens (Echinodermata). Fish Shellfish Immunol 12: $187-200$

Coteur G, Gillan, D, Joly G, Pernet P, Dubois P (2003a) Field contamination of the starfish Asterias rubens by metals. Part 2: effects on cellular immunity. Environ Toxicol Chem 22: $2145-2151$

Coteur G, Gosselin P, Wantier P, Chambost-Mancier Y, Danis B, Pernet P, Warnau M, Dubois P (2003b) Echinoderms as bioindicators, bioassays and impact assessment tools of sediment-associated metals and PCBs in the North Sea. Arch Environ Con Tox 45:190-202 
Coteur G, Pernet P, Gillan D, Joly G, Maage A, Dubois P (2003c). Field contamination of the starfish Asterias rubens by metals. Part 1: Short- and long-term accumulation along a pollution gradient. Environ Toxicol Chem 22: 2136-2144

Coteur G, Corriere N, Dubois P (2004) Environmental factors influencing the immune responses of the common European starfish (Asterias rubens). Fish Shellfish Immun 16:51-63 Coteur G, Danis, B, Dubois P (2005) Echinoderm reactive oxygen species (ROS) production measured by peroxydase, luminol-enhanced chemiluminescence (PLCL) as an immunotoxicological tool. In: Mantraga V (ed) Progress in Molecular and Subcellular Biology Subseries Marine Molecular Biotechnology. Springer-Verlag, Berlin Heidelberg, p 71-83.

Crapp G. 1971. Chronic oil pollution. In: Cowell EB (ed) The ecological effect of oil pollution on Littoral communities. Institute of Petroleum, London, p 187-203

Danis B, Goriely S, Dubois P, Fowler SW, Flamand V, Warnau M (2004a) Contrasting effects of coplanar versus non-coplanar PCB congeners on immunomodulation and CYP1A levels (determined using an adapted ELISA method) in the common sea star Asterias rubens L Aquat Toxicol 69:371-383

Danis B, Wantier P, Flammang R, Dutrieux S, Dubois P, Warnau M (2004b) Contaminant levels in sediments and asteroids (Asterias rubens L. Echinodermata) from the Belgian coast and Scheldt estuary: polychlorinated biphenyls and heavy metals. Sci Total Environ 333:149165

Davis PH, Schultz TW, Spies RB (1981) Toxicity of Santa Barbara seep oil to starfish embryos: Part 2- the growth bioassay. Mar Env Res 5: 287 den Besten PJ (1998) Cytochrome P450 monooxygenase system in Echinoderms. Comp Biochem Physiol 121C: 139-146 
Dean TA, Jewett SC, Laur DR, Smith RO (1996) Injury to epibenthic invertebrates resulting from the Exxon Valdez oil spill. Am Fish Soc Symp 18: 424-439

den Besten PJ, Lemaire P, Livingstone DR, Woodin B, Stegeman JJ, Herwig HJ, Seinen W (1993) Time course and dose response of the apparent induction of the cytochrome P450 monooxygenase system of pyloric caeca microsomes of the female sea star Asterias rubens $\mathrm{L}$. by Benzo[a]pyrene and polychlorinated biphenyls. Aquat Toxicol 26:23-40 den Besten PJ, Valk S, Weerle van E, Nolting RF, Postma JF, Everaarts JM (2001) Bioaccumulation and biomarkers in the seastar Asterias rubens (Echinodermata: Asteroidea) a North Sea field study. Mar Env Res 51: 365-387

Diderich R (2000). Etude des risques des substances contenues dans le fuel transporté par l'ERIKA sur les écosystèmes aquatiques. Rapport 7 du dossier Erika; Institut National de l'Environnement Industriel et des Risques; Ministère de l'Aménagement du territoire et de l'Environnement, Paris, France.

Dubois P, Jangoux M (1990) Stereom morphogenesis and differentiation during regeneration of adambulacral spines of Asterias rubens (Echinodermata, Asteroïdea). Zoomorphology 109: $263-272$

Geffard O, Budzinski H, Le Menach K (2004) Chemical and ecotoxicological characterization of the 'Erika' petroleum: bio-tests applied to petroleum water-accommodated fractions and natural contaminated samples. Aquat Living Resour 17:289-296

Georgiades ET, Holdway DA, Brennan SE, Butty JS, Temara A (2003)The impact of oilderivated products on the behaviour and biochemistry of the eleven-armed asteroid Coscinasterias muricata (Echinodermata). Mar Environ Res 55:257-276

Guns M, Hoeyweghen van P, Vyncke W, Hillewaert H (1999) Trace metals in selected benthic invertebrates from Belgian coastal waters (1981-1996). Mar Pollut Bull 38:1184-1193 
Hooten A J, Highsmith RC (1996) Impact on selected intertidal invertebrates in Herring Bay, Prince William Sound, after the Exxon Valdez oil spill. Am Fish Soc Symp 18: 249-270 Jewett SC, Dean TA, Laur DR (1996) Effect of the Exxon Valdez Oil spill on benthic invertebrates in an oxygen-deficient embayment in Prince William Sound, Alaska. Am Fish Soc Symp 18: 440-447

Kobayashi N (1995) Bioassay data for marine pollution using echinoderms life. In:

Cheremisinoff PN (ed) Encyclopedia of Environmental control technology vol 9, Gulf Publ Co, Houston, p 539-609

Krause PR (1994) Effects of an oil production effluent on gamete genesis and gamete performance in the purple sea urchin (Strongylocentrotus purpuratus, Stimpson). Environ Toxicol Chem 13:1153-1161

Laubier L, Le Moigne M, Flammarion P, Thybaud E, Cossa D (2004) The monitoring programme of the ecological and ecotoxicological consequences of the "Erika" oil spill. Aquat Living Resour 17: 239-241

McIntosh LM, Robinson WE (1999) Cadmium turnover in the hemocytes of Mercenaria mercenaria (L.) in relation to hemocyte turnover. Comp Biochem Phys C 123:61-66 O'Clair CE, Rice SD (1985) Depression of feeding and growth rates of the seastar Evasterias troschelii during long-term exposure to the water-soluble fraction of crude oil. Mar Biol 84: $331-340$

Ordzie CJ, Garofalo GC (1981) Lethal and sublethal effects of short term acute doses of Kuwait crude oil and a dispersant Corexit 9527 on bay scallops, Argopecten irradians (Lamarck) and two predators at different temperatures. Mar Environ Res 5:195-210 Ryder K, Temara A, Holdway DA (2004) Avoidance of crude-oil contaminated sediment by the australian seastar, Patiriella exigua (Echinodermata: Asteroidea). Mar Pollut Bull 49:900-909 
Sommer U, Meusel B, Stielau C (1999) An experimental analysis of the importance of bodysize in the seastar-mussel predator-prey relationship. Acta Oecol 20:81-86

Stronkhorst J, Ariese F, van Hattum B, Postma JF, de Kluijver M, den Besten PJ, Bergmann MJN, Daan R, Murk AJ, Vethaak AD (2003) Environmental impact and recovery at two dumping sites for dredge material in the North Sea. Environ Pollut 124:17-31

Temara A, Nguyen QA, Hogarth AN, Warnau M, Jangoux M, Dubois P. (1997) High sensitivity of skeletogenesis to $\mathrm{Pb}$ in the Asteroid Asterias rubens (Echinodermata). Aquat Toxicol 40:1-10

Temara A, Skei JM, Gillan D, Warnau M, Jangoux M, Dubois P (1998) Validation of the Asteroid Asterias rubens (Echinodermata) as a bioindicator of spatial and temporal trends of $\mathrm{Pb}, \mathrm{Cd}$ and $\mathrm{Zn}$ contamination in the field. Mar Environ Res 45:341-356 Temara A, Gulec I, Holdway DA (1999) Oil-induced disruption of foraging behaviour of the asteroid keystone predator, Coscinasterias muricata (Echinodermata). Mar Biol 133: 501-507 Tronczynski J, Miunschy C, Héas-Moisan K, Guiot N, Truquet I, Olivier N, Men S, Furaut A (2004). Contamination of the Bay of Biscay by polycyclic aromatic hydrocarbons (PAHs) following the T/V "Erika" oil spill. Aquat Living Resour 17: 243-259 Vashchenko MA (1980) Effects of oil pollution on the development of sex cells in sea urchins. Helgoländ wiss Meer 33: 297-300

Watts SA, Lawrence JM (1990) The effect of temperature and salinity interactions on rightning, feeding and growth in the sea star Luidia clathrata (Say). Mar Behav Physiol $17: 159-165$.

Zar JH (1996) Biostatistical analysis. Prentice-Hall Inc., Englewood Cliffs 
Table 1. List of PAH compounds studied with the internal standards used for GC/MS analysis

\begin{tabular}{|c|c|c|}
\hline Compound & Abreviation & Internal standard \\
\hline naphtalene & & $\mathrm{Nd} 8$ \\
\hline acenaphtylene & & $\mathrm{Nd} 8$ \\
\hline acenaphtene & & $\mathrm{Nd} 8$ \\
\hline fluorene & & Pd10 \\
\hline phenanthrene & Phe & Pd10 \\
\hline anthracene & & Pd10 \\
\hline fluoranthene & & Fluod10 \\
\hline benzo(a)anthracene & & Chrys d12 \\
\hline pyrene & Pyr & Pyrd10 \\
\hline triphene + chrysene & Chrys & Chrys d 12 \\
\hline benzo $(b+j+k)$ fluoranthene & & BePd12 \\
\hline benzo(e)pyrene & $\mathrm{BeP}$ & BePd12 \\
\hline benzo(a)pyrene & $\mathrm{BaP}$ & BaPd12 \\
\hline perylene & & BaPd12 \\
\hline indeno(1,2,3-cd)pyrene & & BPd12 \\
\hline dibenz(a)anthracene $+\mathrm{DaC}$ & & BPd12 \\
\hline benzo(ghi)peryleneP & & BPd12 \\
\hline Sum of unsubstituted PAHS & uns-PAHs & \\
\hline Sum methylnaphtalene & & $\mathrm{Nd} 8$ \\
\hline $\begin{array}{l}\text { Sum methylphenanthrenes and } \\
\text { dimethylphenanthrene }\end{array}$ & MPhe & $\operatorname{Pd} 10$ \\
\hline methylchrysene & MChrys & Chrysd12 \\
\hline Sum of methylated PAHS & $M-P A H S$ & \\
\hline dibenzothiophene & DBT & DBTd8 \\
\hline methyldibenzothiophene & MDBT & DBTd8 \\
\hline 2,1 benzonaphtothiophene & & Chrysd12 \\
\hline Sum of all analysed PAHs & Sum PAHs & \\
\hline
\end{tabular}

Table 2 Characterisation of PAH levels in organs of starfish

\begin{tabular}{lllll}
\hline & \multicolumn{2}{c}{ Body wall } & \multicolumn{2}{c}{ Pyloric caeca } \\
& Aber & Piriac & Aber & Piriac \\
\hline uns-PAHs & $38 \%$ & $32 \%$ & $41 \%$ & $30 \%$ \\
M-PAHs & $62 \%$ & $68 \%$ & $59 \%$ & $70 \%$ \\
\hline Phe & $71210^{-4}$ & $50610^{-4}$ & $34610^{-4}$ & $26210^{-4}$ \\
Alkyl-Phe- & $31910^{-3}$ & $34910^{-3}$ & $18010^{-3}$ & $42810^{-3}$ \\
\hline DBT & $3110^{-4}$ & $7810^{-4}$ & $3910^{-4}$ & $2410^{-4}$ \\
MDBT & $<10^{-4}$ & $12210^{-4}$ & $15610^{-4}$ & $17610^{-4}$ \\
\hline Chrys & $5610^{-4}$ & $47810^{-4}$ & $14610^{-4}$ & $73410^{-4}$ \\
MChrys & $<10^{-4}$ & $178710^{-4}$ & $3910^{-4}$ & $198410^{-4}$ \\
\hline
\end{tabular}

Piriac : oil-exposed population; Aber : control. All data are means, $n=2$ pools (10 starfish by pool). uns- (unsubstituted) and M-PAH (methylated PAH) are expressed as percent of the sum of all analyzed PAHs. Phe (phenanthrene), DBT (dibenzothiophene), Chrys (chrysene) and Alkyl-Phe (Alkyl-phenanthrene), -DBT and -Chrys are expressed in $\mu \mathrm{g} \mathrm{g}^{-1}$ lipids. Lipid contents are those measured at day 58 (Fig.2).

Table 3. Kinetics of PAH uptake and results of the quadratic curve. 


\begin{tabular}{lllll}
\hline & \multicolumn{3}{l}{ Curve Fitting } & TF \\
& \multicolumn{1}{c}{$p$} & $\mathrm{R}^{2}$ & $\mathrm{I}$ (days) & \\
\hline Sum PAHs & $<110^{-3}$ & 0.823 & 9.48 & 0.110 \\
uns-PAHs & $<110^{-3}$ & 0.881 & 9.11 & 0.125 \\
Pyr & $<110^{-3}$ & 0.909 & 9.19 & 0.121 \\
Phe & $<110^{-3}$ & 0.874 & 8.82 & 0.159 \\
DBT & $<110^{-3}$ & 0.756 & 9.37 & 0.118 \\
Chrys & $<110^{-3}$ & 0.849 & 10.12 & 0.086 \\
\hline
\end{tabular}

$(\mathrm{n}=2$ pools of 10 starfish) fed contaminated mussels during the agametogenic stage

(1 mussel per individual starfish per day. PAH: $268.5 \pm 78.5 \mu \mathrm{g} / \mathrm{g}$ lipids).

(I): inflection point of the fitted curve, (TF): transfer factor, $P$ : curve fitting probability,

$\mathrm{R}^{2}$ : correlation coefficient, Sum PAHs: sum of all analyzed PAHs,

uns-PAHs: sum of analyzed unsubstituted PAHs,

Pyr: pyrene, Phe: phenanthrene, DBT: dibenzothiophene, Chrys: chrysene.

Table 4. PAH loss in the pyloric caeca of starfish and result of the curve fitting for certain PAHs.

\begin{tabular}{llllll}
\hline & $p$ & $\mathrm{R}^{2}$ & $\mathrm{D}$ & $\mathrm{g}$ & $\mathrm{h}$ \\
\hline Sum PAHs & $<110^{-3}$ & 0.958 & 92.84 & 3.50 & 3.03 \\
uns-PAHs & $<110^{-3}$ & 0.983 & 21.323 & 1.45 & 2.77 \\
Pyr & $<110^{-3}$ & 0.980 & 2.97 & -0.0318 & 3.50 \\
Phe & $<110^{-3}$ & 0.976 & 7.05 & 0.284 & 2.02 \\
DBT & $210^{-3}<\mathrm{p}<510^{-3}$ & 0.856 & 2.27 & -0.0065 & 2.12 \\
Chrys & $<110^{-3}$ & 0.926 & 4.744 & 0.0117 & 3.42 \\
\hline
\end{tabular}

$\mathrm{n}=1$ pool of 4 starfish fed with 2 uncontaminated mussels per individual per week over 23 days.

$P$ : curve fitting probability, $\mathrm{R}^{2}$ : correlation coefficient, $\mathrm{D}, \mathrm{g}$ : parameters of the fitted equation (in $\mu \mathrm{g} \mathrm{g}^{-1}$ of lipids), h: half-life of the compounds (in days). Sum PAHs: sum of all analyzed PAHs, uns-PAHs: sum of analyzed unsubstituted PAHs, Pyr: pyrene, Phe: phenanthrene, DBT: dibenzothiophene, Chrys: chrysene.

Table 5. Comparison of PAH load in starfish pyloric caeca in the field and under experimental conditions.

\begin{tabular}{|c|c|c|c|c|c|}
\hline \multirow[t]{3}{*}{2} & \multirow{3}{*}{$\begin{array}{c}\text { Field } \\
\text { Day } 58 \\
\text { Piriac }\end{array}$} & \multicolumn{4}{|c|}{ In-lab experiments } \\
\hline & & Short term & \multicolumn{2}{|c|}{ Long term contamination } & \multirow{2}{*}{$\begin{array}{l}\text { End of the PAH } \\
\text { loss experiment }\end{array}$} \\
\hline & & & Adults ${ }^{2}$ & Juveniles $^{3}$ & \\
\hline Sum PAHs & 0.97 & $23.16(24)$ & $49.27(51)$ & $86.15(89)$ & $3.50(4)$ \\
\hline uns-PAHs & 0.29 & $6.53(23)$ & $11.37(40)$ & $21.43(75)$ & $1.45(5)$ \\
\hline Pyr & 0.062 & $0.79(13)$ & $1.19(19)$ & $2.73(44)$ & $-0.032(-1)$ \\
\hline Phe & 0.026 & $2.29(87)$ & 3.12 (119) & $7.12(272)$ & $0.28(11)$ \\
\hline DBT & 0.0024 & $0.46(193)$ & $0.54(228)$ & $1.92(803)$ & $-0.0065(-3)$ \\
\hline Chrys & 0.073 & $1.00(14)$ & $1.72(23)$ & $3.97(54)$ & $0.012(0.2)$ \\
\hline
\end{tabular}




\section{Figure Captions}

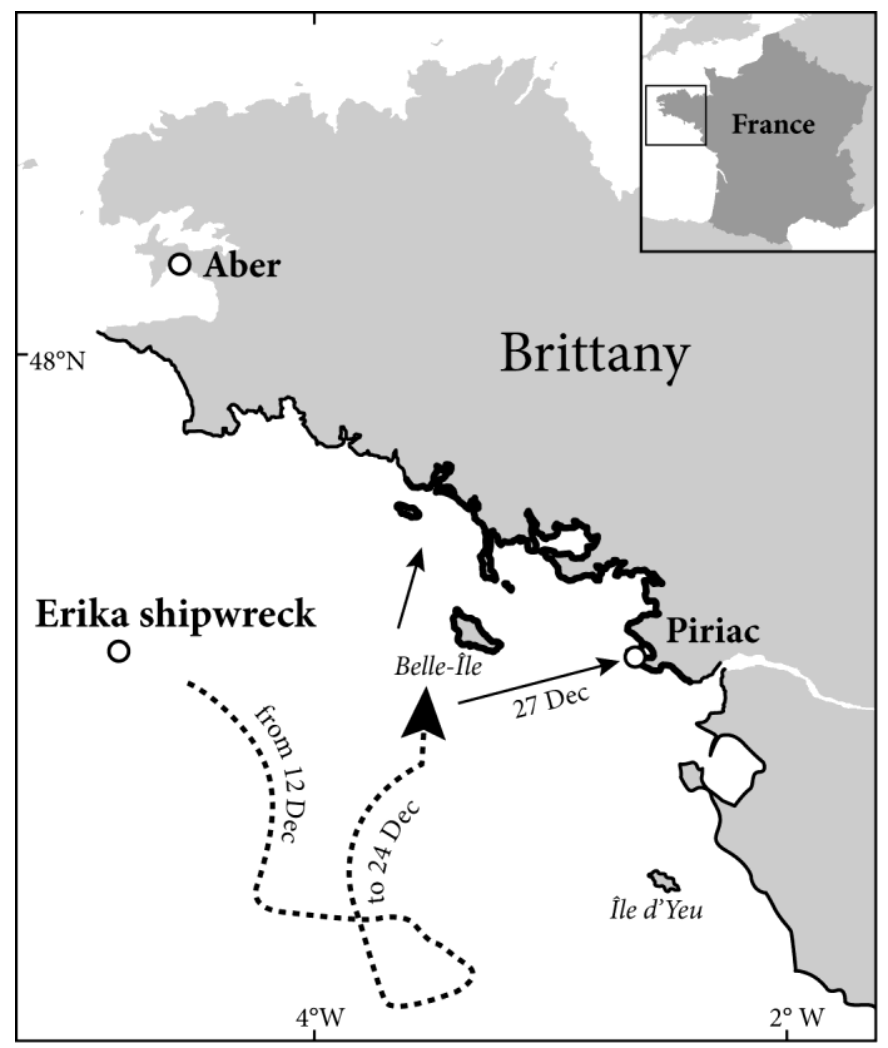

Figure 1: Map showing the location of field sites and of the Erika shipwreck. Piriac was contaminated by oil from Erika, whereas Aber remained free of this contamination. —: shoreline affected by the oil spill; dotted line: the main oil slick drift from December 12 to December 24, 1999 (from Laubier et al., 2004). 


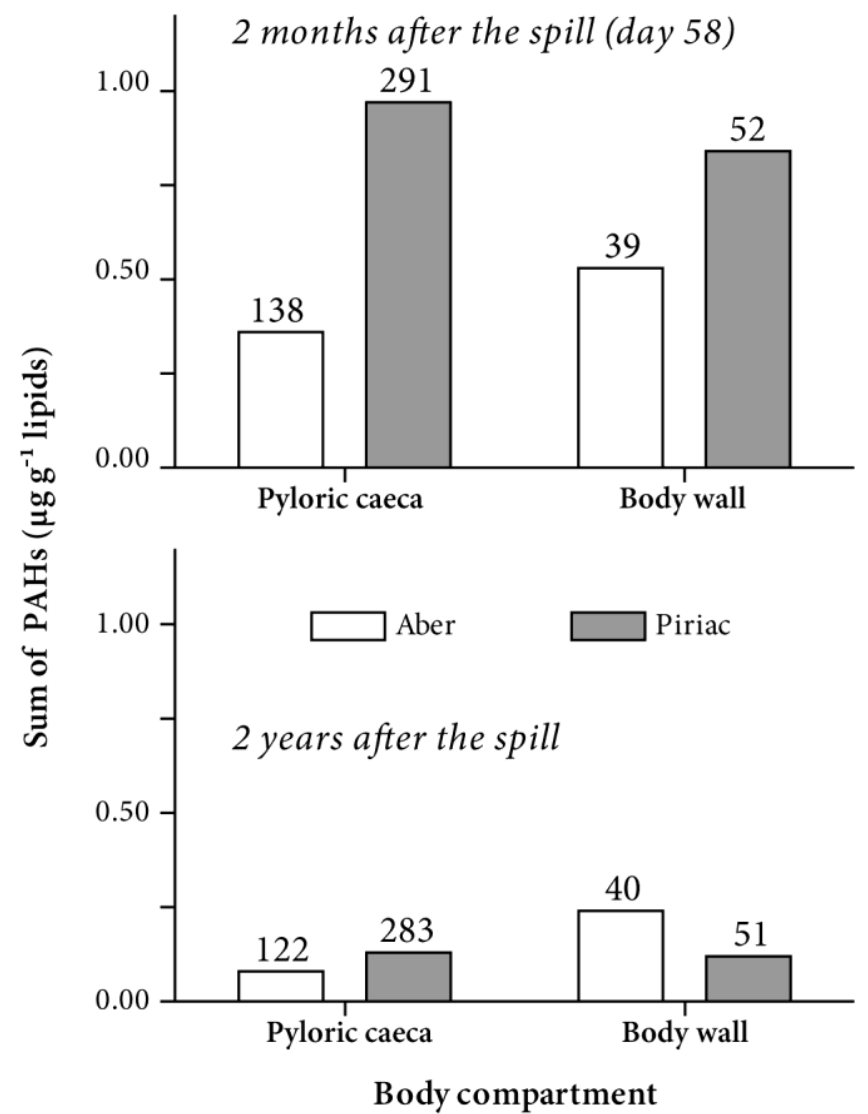

Figure 2: Total PAH levels in field-collected starfish 58 days and two years after the Erika oil spill. Piriac: oil-exposed site; Aber: reference site. All data are means, $n=2$ pools (10 starfish per pool). The numbers written above the histogram bars indicate the lipid contents $\left(\mathrm{mg} \mathrm{g}^{-1}\right)$ of the organs. 

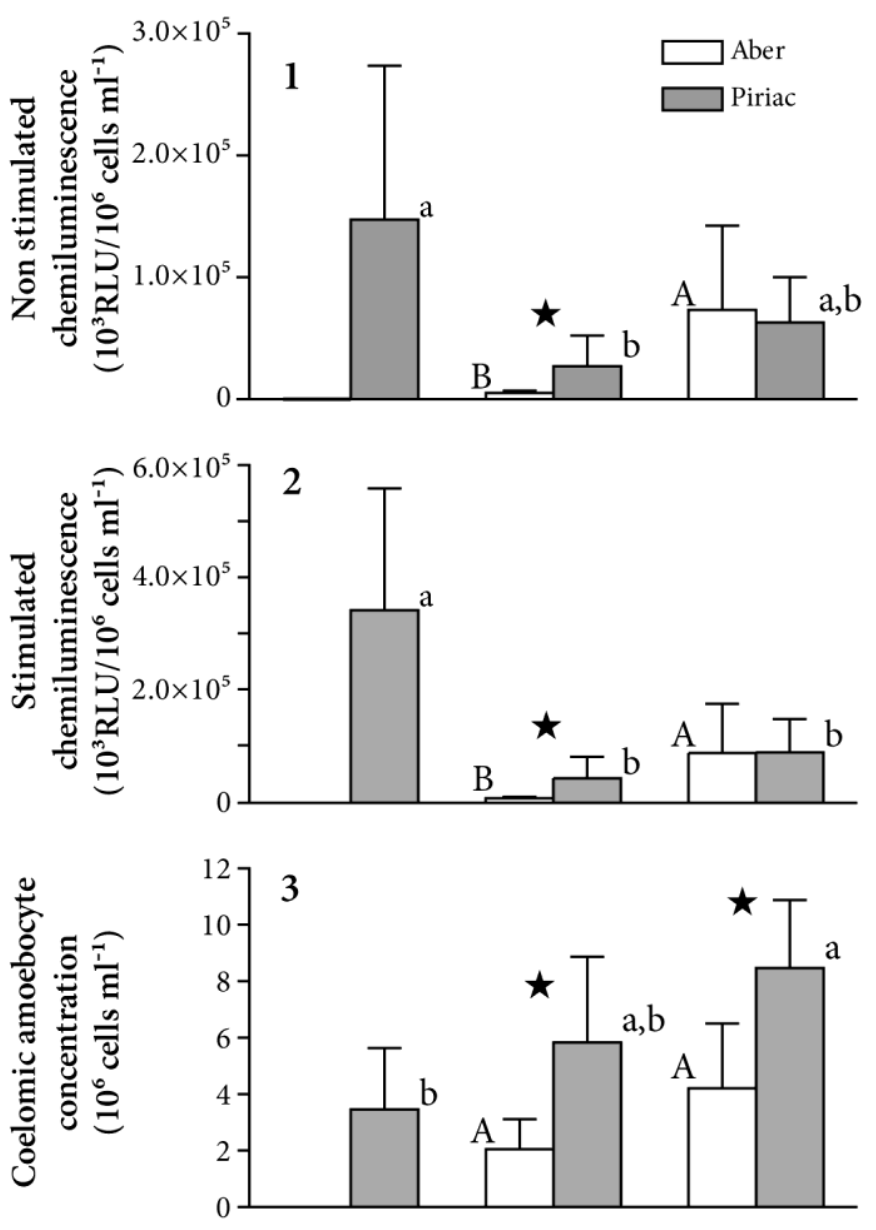

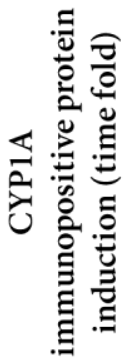

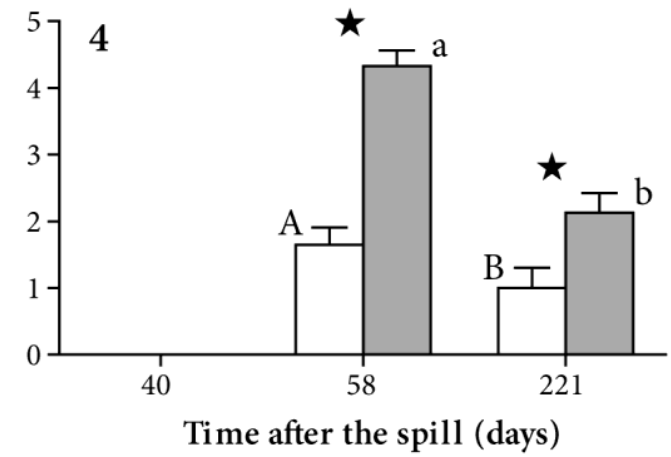

Figure 3: Temporal changes in biomarker responses after the oil spill in field-collected starfish from Piriac: oil-exposed site and Aber: reference site. All data are means \pm standard deviations. 1) ROS production by resting amoebocytes $(\mathrm{n}=5$ or 10$), 2)$ ROS production by stimulated amoebocytes $(\mathrm{n}=5$ or 10$), 3)$ Coelomic amoebocyte concentration $(\mathrm{n}=5$ or 10$)$ and 4$)$ CYP1A induction $(\mathrm{n}=4)$. Histogram bars with the same letters are not significantly different. Lower case letters are for comparison of dates at Piriac, whereas capital letters are for comparison of dates at Aber, and indicates a statistical difference between the sites at a given date. (ROS: reactive oxygen species; CYP1A: Cytochrome P450 immunopositive protein content). 


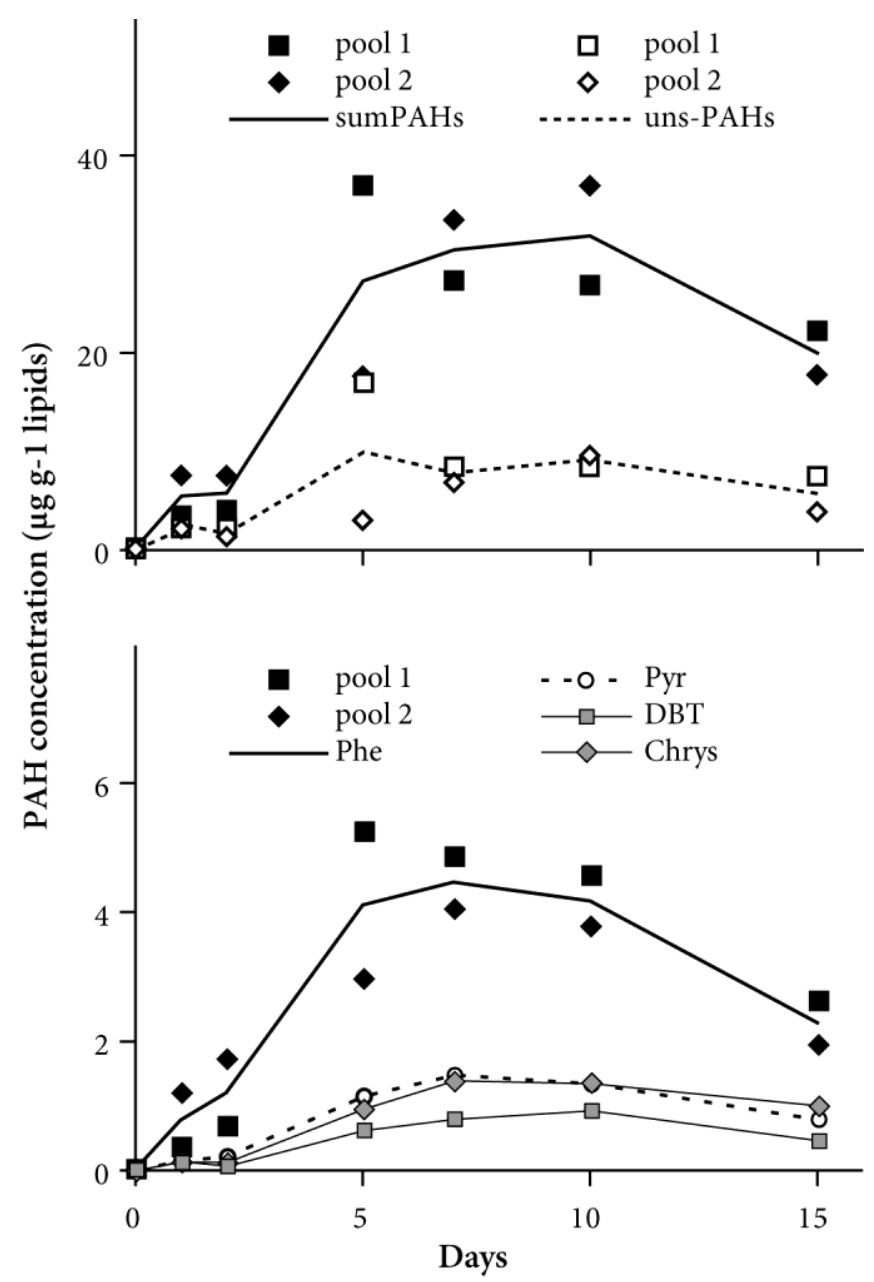

Figure 4: Kinetics of PAH uptake in the pyloric caeca of starfish $(n=2$ pools of 10 starfish $)$ fed with contaminated mussels over the agametogenic stage. Sum PAHs: sum of PAHs analyzed in this study, uns-PAHs: sum of unsubstituted PAHs, Pyr: pyrene, Phe: phenanthrene, DBT: dibenzothiophene, Chrys: chrysene. 

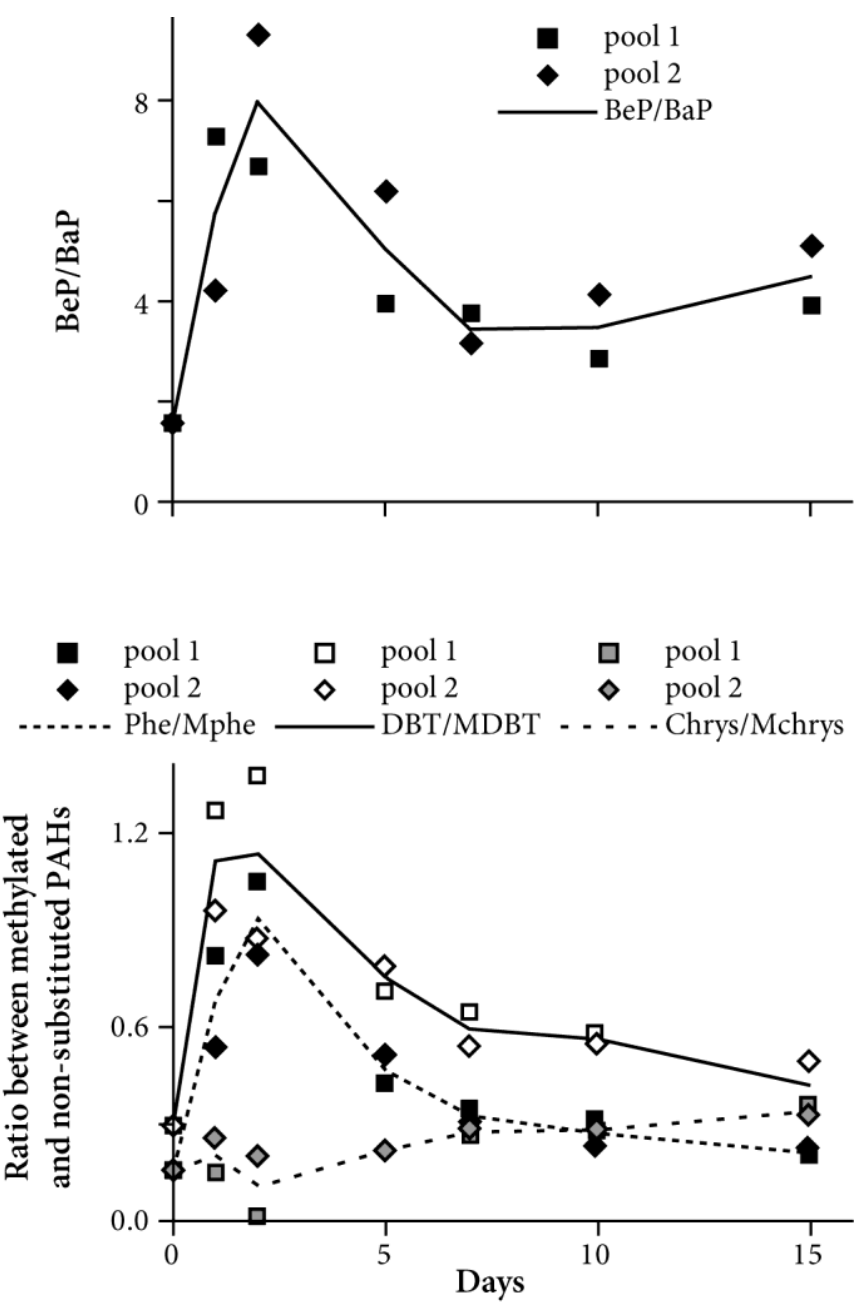

Figure 5: Temporal changes in biotransformation ratios in the pyloric cacea of starfish $(\mathrm{n}=2$ pools of 10 starfish) fed with contaminated mussels. BeP: Benzo(e)pyrene, BaP: Benzo(a)pyrene, Phe: phenanthrene, MPhe: methyl-phenanthrene, DBT: dibenzothiophene, MDBT: methyldibenzothiophene, Chrys: chrysene, MChrys: methyl-chrysene. 


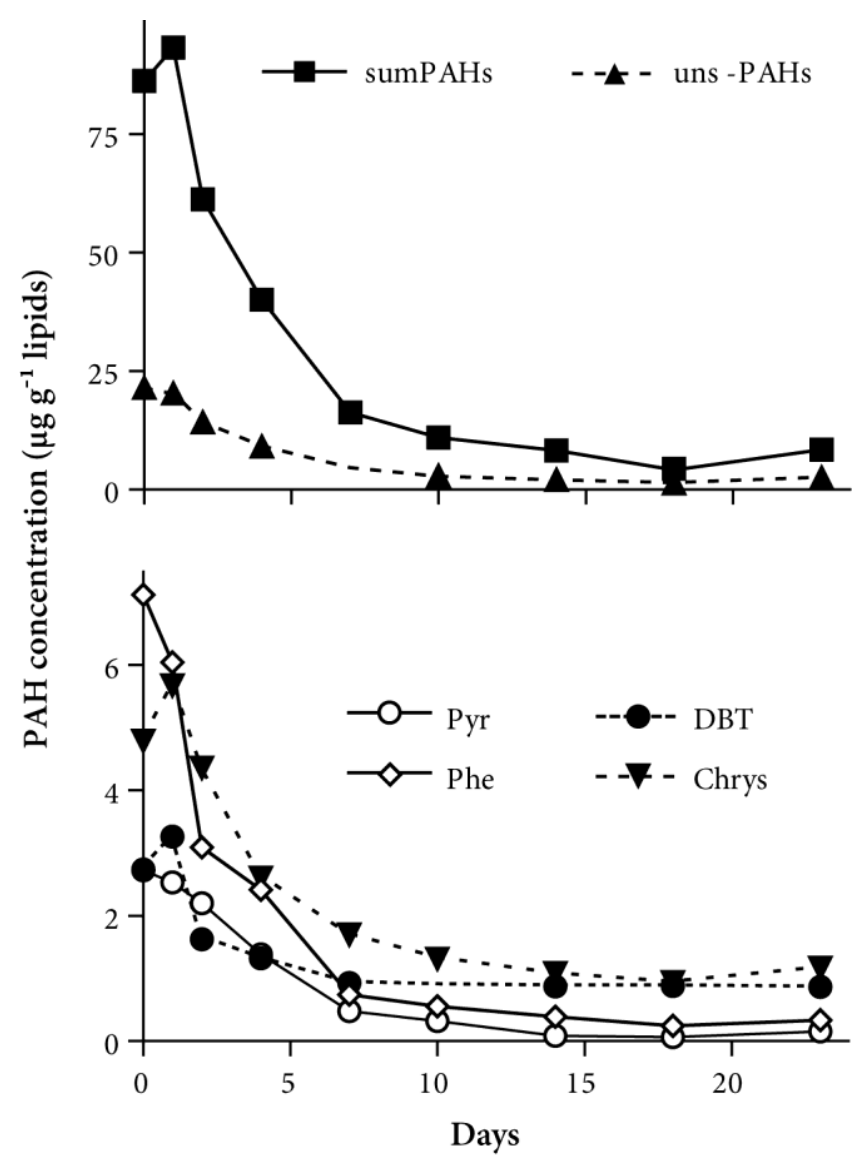

Figure 6: Loss kinetics of PAH in pyloric cacea of starfish $(n=1$ pool of 4 starfish) fed with uncontaminated mussels over 23 days. sumPAHs: sum of all analysed PAHs, uns-PAHs: sum of nonsubstituted PAHs, Pyr: pyrene, Phe: phenanthrene, DBT: dibenzothiophene, Chrys: chrysene. 